Syntax Literate: Jurnal Ilmiah Indonesia p-ISSN: 2541-0849

e-ISSN: 2548-1398

Vol. 5, No. 9, September 2020

\title{
MANAJEMEN KOMUNIKASI INFID DALAM PENDAMPINGAN PEMDA KABUPATEN CIREBON DAN KOTA YOGYAKARTA MENCAPAI SUSTAINABLE DEVELOPMENT GOALS
}

\section{Salsabila Pratiwi dan Yayu Sriwartini}

Fakultas Ilmu Sosial Dan Ilmu Politik (FISIP) Universitas Nasional Depok, Indonesia Email: salsabilaapratiwi98@gmail.com dan yayu_sriwartini@yahoo.com

\section{Abtract}

This research raises the implementation of communication management in nongovernmental organizations, namely the International NGO Forum on Indonesian Development (INFID). One of the focuses of INFID's work is assisting local governments in Cirebon and Yogyakarta Regencies to achieve the goals of sustainable development goals (SDGs). Local governments have an important role in holding SDGs in the regions. Cirebon and Yogyakarta Regencies are two regions that have poverty issues that need to be tackled which are in line with the SDGs goal of zero poverty. The role of communication management is needed because local government assistance is a difficult focus of work. It is based on performance and decisions that can affect the welfare of society. The purpose of this study is to provide an overview of planning, organizing, mobilizing or directing and controlling in terms of communication as an effort to assist local governments in Cirebon and Yogyakarta Regencies carried out by non-governmental organizations. In this study, researchers used concepts from communication management and organizational information theory. The methodology in this study uses a qualitative approach, descriptive research type, data collection methods use interviews and documentation and uses data validity techniques consisting of triangulation, certainty, extending observations and also dependence. The results showed that the communication management carried out by INFID involved multi-stakeholders either from the government or other non-governmental organizations and by means of the SDGs. In terms of organizational information theory, INFID is described as an organization formed from communication activities in every stage of communication management.

Keywords: Communication Management; Mentoring; Sustainable Development Goals

\begin{abstract}
Abstrak
Penelitian ini mengangkat implementasi manajemen komunikasi dalam organisasi non pemerintah yaitu International NGO Forum on Indonesian Development (INFID). Salah satu fokus kerja INFID yaitu mendampingi pemerintah daerah di Kabupaten Cirebon dan Yogyakarta untuk mencapai tujuan sustainable development goals (SDGs). Pemerintah daerah memiliki peranan penting dalam menghelat SDGs di daerah. Kabupaten Cirebon dan Yogyakarta merupakan dua daerah yang memiliki isu kemiskinan yang perlu ditanggulangi dimana sesuai dengan tujuan satu SDGs yaitu tanpa kemiskinan. Peran manajemen komunikasi diperlukan karena
\end{abstract}


pendampingan pemerintah daerah adalah fokus kerja yang tidak mudah. Hal itu didasari pada kinerja dan keputusannya yang dapat mempengaruhi kesejahteraan masyarakat. Tujuan penelitian ini untuk memberikan gambaran mengenai perencanaan, pengorganisasian, penggerakan atau pengarahan serta pengendalian dari sisi komunikasi sebagai upaya untuk pendampingan pemerintah daerah Kabupaten Cirebon dan Yogyakarta yang dilakukan oleh organisasi non pemerintah. Dalam penelitian ini, peneliti menggunakan konsep dari manajemen komunikasi dan teori informasi organisasi. Metodologi dalam penelitian ini menggunakan pendekatan kualitatif, jenis penelitian deskriptif, metode pengumpulan data menggunakan wawancara dan dokumentasi serta menggunakan teknik keabsahan data yang terdiri dari triangulasi, kepastian, memperpanjang pengamatan dan juga kebergantungan. Hasil penelitian menunjukkan bahwa manajemen komunikasi yang dilakukan INFID melibatkan multipihak baik dari pemerintah ataupun organisasi non pemerintah lainnya dan dengan cara kerja SDGs. Dari sisi teori informasi organisasi, INFID dijelaskan sebagai organisasi yang dibentuk dari aktivitasaktivitas komunikasi dalam setiap tahapan manajemen komunikasi.

Kata kunci : Manajemen Komunikasi, Pendampingan, Sustainable Development Goals

\section{Pendahuluan}

Indonesia merupakan salah satu negara yang berpartisipasi dalam penyelengaraan Sustainable Development Goals (SDGs). Pelaksanaan SDGs di Indonesia memiliki tantangan. Melansir dari publikasi INFID, tantangan yang dimaksud adalah komunikasi yang dilakukan, pembiayaan dan menyiapkan daerah untuk mengadopsi serta melaksanakan SDGs pada masing-masing Kabupaten dan Kota. Menurut Kepala Sekretariat Nasional SDGs sebagaimana yang dikutip oleh liputan6.com, keberhasilan tujuan SDGs membutuhkan kolaborasi seluruh pemangku kepentingan yakni pemerintah pusat dan pemerintah daerah, pelaku usaha, akademisi dan praktisi, serta organisasi masyarakat dan media. Peran strategis pemerintah daerah dalam pencapaian SDGs sangat penting untuk memastikan implementasi pelayanan publik dan indikator SDGs berjalan baik di tingkat lokal.

Pemerintah daerah memiliki peranan yang penting dalam pelaksanaan SDGs karena didukung dari pemberlakukan desentralisasi di Indonesia yakni dua pertiga nasib dan kualitas hidup warga. Selain itu, pemerintah daerah dianggap lebih dekat dengan warganya, memiliki wewenang dan dana, dapat melakukan inovasi serta menjadi ujung tombak penyedia layanan publik dan berbagai kebijakan serta program pemerintah (Hoelman, Parhusip, Eko, Bahagijo, \& Santono, 2016).

Berbicara mengenai SDGs lebih jauh, maka perlu ditinjau setiap tujuan yang ada di dalamnya, salah satunya adalah tanpa kemiskinan atau no poverty dengan tujuan utama mengakhiri segala bentuk kemiskinan dimana pun. Hal itu didasarkan bahwa isu kemiskinan ini merupakan isu yang penting bagi negara berkembang di Indonesia. Tujuan tanpa kemiskinan menjadi poin pertama dalam SDGs. Pengentasan kemiskinan ini juga tentu akan sangat terkait dengan tujuan global lainnya. Data yang diambil dari Badan Perencanaan Pembangunan Daerah (Bappeda) Provinsi Daerah Istimewa 
Yogyakarta (DIY), kemisikinan masih menjadi problem di berbagai dunia, termasuk Indonesia. Untuk itu, penghilangan kemiskinan dan kelaparan pada tahun 2030 merupakan tulang punggungnya. Penghilangan kemiskinan ini dijadikan tujuan utama dalam SDGs. Pada proses pelaksanaannya pengembangan kawasan erat kaitannya dengan pemberdayaan masyarakat. Pemberdayaan masyarakat sendiri memiliki tujuan guna menciptakan masyarakat yang lebih mandiri, sejahtera, dan partisipatif dalam agenda pembangunan (Avianto, 2017).

Radar Cirebon mengutip Badan Pusat Statistik (BPS) melaporkan angka kemiskinan di Indonesia mencapai 9,41\% dari jumlah per Maret 2019 atau mencapai 25,14 juta jiwa. Jika dibandingkan dengan Maret 2018 yang berada di angka 9,82\% atau 25,95 juta jiwa, angka kemiskinan sebesar 41 basis poin (bps) atau sebanyak 810 ribu jiwa. Bersumber pada data BPS yang dilansir oleh Radar Cirebon, penurunan kemiskinan hampir terjadi di seluruh pulau di Indonesia. Apabila dirinci lebih lanjut, penduduk miskin paling banyak masih terdapat di Pulau Jawa dengan jumlah 13,34 juta jiwa atau 8,94\%. Menurut data BPS 2019, di pulau Jawa, provinsi yang memiliki angka kemiskinan di atas angka nasional terdapat di DIY di peringkat ke 12 per Juli 2019. Provinsi lainnya seperti Jawa tengah di peringkat ke- 15 dengan angka kemiskinan 10,8\% sedangkan Jawa Timur di peringkat ke- 16 dengan angka kemiskinan 10,37\%. Adapun provinsi yang memiliki angka kemiskinan terendah adalah DKI Jakarta sebesar 3,47\% dan Bali 3,79\% . Jumlah penduduk miskin DIY yaitu 460.100 jiwa.

Di sisi lain, data yang dilansir dari penakhatulistiwa.com yakni terdapat Kabupaten Cirebon yang memiliki program penanggulangan kemiskinan sebagai program prioritas pemerintah. Hal itu dikarenakan kabupaten ini mempunyai persentasi penduduk miskin sebanyak 10,70\%. Kemiskinan di Kabupaten Cirebon dikarenakan perencanaan pemerintah desa yang lebih mengutamakan pembangunan infrastruktur dibandingkan pemberdayaan masyarakatnya karena tidak selamanya problem kemiskinan dapat dituntaskan dengan infrastruktur.

Dari beberapa paparan mengenai SDGs dan isu pembangunan seperti kemiskinan, terdapat salah satu non government organization (NGO) yang memiliki kekhususan advokasi dalam hal-hal tersebut. International NGO Forum on Indonesian Development (INFID) adalah organisasi non-pemerintah yang sejak awal pendiriannya, INFID telah memainkan peran penting dalam pembangunan dan proses demokratisasi Indonesia. Salah satu kerja program SDGs yang tengah dijalankan yaitu melakukan pendampingan bagi pemangku kepentingan di daerah yang salah satunya adalah pemerintah daerah dalam pelaksanaan dan pencapaian SDGs. Dalam upaya pendampingan kepada pemangku kepentingan di daerah yang salah satunya adalah pemerintah daerah, perlu adanya jalinan komunikasi yang menjadi titik perhatian suatu organisasi yakni pelaksanaan komunikasi yang baik dan efektif. Berangkat dari hal tersebut, manajemen komunikasi merupakan hal yang penting terlebih dalam hal pendampingan pemerintah daerah bagi INFID sebagai organisasi yang melakukan kerja pada SDGs.

Penelitian tentang manajemen komunikasi ini masih perlu diteliti, terutama yang kaitannya mengenai komunikasi tentang SDGs berikut perannya dalam pendamping 
desa untuk pembangunan, salah satunya menurut (Triyanto, 2018) bahwa kinerja pendamping desa dalam membangun kemandirian desa sangat penting untuk dikaji, karena berdasarkan nawa cita presiden Joko Widodo desa diharapkan dapat membangun perekonomian masyarakat dengan cara membangun usaha-usaha desa, oleh karena itu dengan adanya pendamping desa diharapkan dapat mensukseskan program tersebut. Program tersebut menyiratkan proses dimana informasi, interpretasi dan pendapat sehubungan dengan isu-isu yang ada dapat dipertukarkan dan didiskusikan. Pembangunan desa menjadi kunci dan fondasi pembangunan daerah dan nasional, sehinggaperan pendamping desa diharapkan dapat mempercepat ketertinggalan dan kesejahteraanmasyarakat (Saragih \& Agung, 2018). Komunikasi juga bukan hanya tentang menyediakan informasi terkait keberlanjutan saja tetapi juga meningkatkan kesadaran untuk pertimbangan keberlanjutan. Penelitian ini mengaitkan dengan manajemen komunikasi dikarenakan manajemen komunikasi merupakan cara yang dapat menyelaraskan berbagai unsur komunikasi untuk mencapai tujuan tersebut. Manajemen dalam hal ini diperlukan bukan hanya mencapai tujuan tetapi juga menjaga keseimbangan serta mencapai efisiensi dan efektifitas (Abidin, 2015)

Manajemen komunikasi dilakukan untuk menyusun perencanaan, mengorganisasikan, menggiatkan komunikator dalam hal mensinergikan seluruh bagian dari INFID baik dari tingkat atas hingga anggota, pesan yang akan disampaikan, media yang digunakan, komunikan yang disasar dan pengaruh yang diinginkan serta mengontrol atau mengawasi komunikator, penyajian pesan, pemilihan dan penggunaan media, pemilihan dan penetapan komunikan atau khalayak serta pengaruh yang diharapkan. Manajemen komunikasi yakni ilmu yang mempelajari bagaimana mengelola informasi untuk mencapai tujuan (Syamsi, 2015); (Suprapto, 2011).

Selain itu, pada fokus kerja pendampingan pemerintah daerah merupakan hal yang tidak mudah. Hal itu didasari pada kinerja dan keputusan pemerintah daerah yang dapat mempengaruhi kesejahteraan masyarakatnya, terutama pada hal yang kompleks yaitu pengurangan kemiskinan (Sarmiati, 2014); (Azwar, 2014). Komunikasi yang dilakukan INFID dalam pendampingan itulah yang perlu dikondisikan dan dilaksanakan dengan efektif serta dapat dipertanggungjawabkan. Dalam hal ini, segala bentuk komunikasi di pendampingan yang dilakukan oleh INFID juga secara tidak langsung membuka pikiran pemerintah daerah Kabupaten Cirebon dan Yogyakarta untuk mengambil keputusan dalam setiap kebijakannya.

Hal yang perlu dipertanggungjawabkan bukan hanya sekadar menyampaikan pesan berupa informasi, tanggapan serta masukan agar tidak terjadi kekeliruan dalam pelaksanaan pendampingan (Fatimah, Arifin, \& Sumpena, 2019). Lebih dari itu, unsurunsur komunikasi perlu diidentifikasi dan direncanakan agar tepat sasaran dan sesuai tujuan yaitu pengurangan kemiskinan. Unsur-unsur komunikasi ini lah yang menjadi penting, bukan hanya pada satu tahapan yakni perencanaan saja, tetapi juga dalam tahapan lainnya. Hal itu didasari dengan manajemen komunikasi yang memiliki sinergitas dengan perkembangan teknologi informasi dan komunikasi dapat mendorong keberhasilan pemberdayaan pembangunan (Suhaeri, 2018). Komunikasi merupakan 
salah satu jalan keluar bagi permasalahan yangkini terjadi. Strategi pada hakikatnya serupa dengan perencanaan dan menejemen sedangkan strategi digunakan untuk sampai ke tujuan.

Dua daerah yang telah dijabarkan oleh peneliti yakni Yogyakarta dan Kabupaten Cirebon memiliki isu kemiskinan yang serius. Kabupaten Cirebon ini merupakan bagian provinsi Jawa Barat yang merupakan provinsi terpadat dan juga memiliki permasalahan kemiskinan sebagai isu penting yang perlu ditanggulangi. Di sisi lainnya, Yogyakarta merupakan provinsi di Jawa yang memiliki angka kemiskinan di atas angka nasional. Selain itu DI Yogyakarta memiliki proses Pemberdayaan masyarakat yang mengaktualisasikan potensi yang sebenarnya telah dimiliki oleh individu dalam masyarakat untuk mengorganisir diri mereka sendiri (Kartika, 2012).

Berdasarkan dari latar belakang yang telah dipaparkan, maka peneliti bermaksud untuk melakukan penelitian berjudul "Manajemen Komunikasi INFID dalam Pendampingan di Kabupaten Cirebon dan Kota Yogyakarta untuk Mencapai Tujuan Sustainable Development Goals". Adapun tujuan penelitian ini adalah untuk mengetahui bagaimana manajemen komunikasi INFID dalam pendampingan di Kabupaten Cirebon dan Kota Yogyakarta untuk mencapai tujuan sustainable development goals?

\section{Metode Penelitian}

Wawancara mendalam kepada staf internal INFID yang terdiri dari 2 key informan dan 1 informan. Wawancara dilakukan di kantor sekretariat INFID di Jalan Jatipadang Raya Kav.3 Nomor 105, Pasar Minggu. Dokumentasi merupakan pelengkap dari penggunaan wawancara dalam penelitian kualitatif (Sugiyono, 2014). Dokumentasi dalam penelitian ini berupa studi pustaka dan rekaman arsip.

Data primer diperoleh dari staf internal INFID yang diwakili oleh Ibu Tatat sebagai program manager, Pak Bona Tua sebagai program officer SDGs serta Ibu Megawati sebagai program officer inequality. Data sekunder diperoleh dari riset, studi, buku-buku panduan yang dipublikasikan oleh INFID, dokumentasi foto, penelusuran website INFID serta arsip pekerjaan pendampingan seperti workplan ataupun action plan. Penelitian ini menggunakan uji keabsahan data, diantaranya triangulasi yang terdiri dari triangulasi sumber dan triangulasi metode, kepastian (confermability), memperpanjang pengamatan serta kebergantungan (depandibility).

Dalam mengolah dan menganalisis data, peneliti melakukan tahapan yaitu mereduksi data dari data yang didapat dari wawancara dan dokumentasi. Data yang diambil yaitu terkait dengan manajemen komunikasi INFID dalam hal pendampingan di Kabupaten Cirebon dan Kota Yogyakarta dalam mencapai tujuan SDGs. Selain datadata yang tidak terkait kebutuhan materi penelitian, maka dieliminasi dan tidak digunakan.

Langkah kedua yaitu mendisplay atau menyajikan data berupa teks yang bersifat naratif. Tujuan dari mendisplay data adalah memudahkan untuk memahami apa yang 
terjadi serta merencanakan kerja selanjutnya berdasarkan apa yang dipahami. Lagkah terakhir dalam penelitian ini adalah penarikan kesimpulan.

Uji analisis data dalam penelitian ini menggunakan metode kualitatif dengan jenis deskriptif. Penyajian data deskriptif kualitatif dipaparkan ke dalam sebuah narasi yang sistematis serta dikuatkan oleh kutipan langsung dari para narasumber yang telah ditentukan maupun dari data sekunder lainnya. Hal tersebut seperti apa yang dipaparkan oleh Moleong yaitu laporan-laporan penelitian deskriptif kualitatif akan berisi kutipankutipan data untuk memberi gambaran penyajian laporan tersebut (Moleong, 2019). Selain dipaparkan secara narasi, terdapat data yang disajikan dengan tabel sehingga dapat memberikan gambaran manajemen komunikasi terutama dalam tahapan actuating di kedua daerah, yaitu Kabupaten Cirebon dan Kota Yogyakarta.

\section{Hasil dan Pembahasan}

\section{Tahap Perencanaan Komunikasi INFID dalam Pendampingan Kabupaten Cirebon dan Kota Yogyakarta}

Perencanaan (planning) merupakan langkah awal dalam unsur manajemen. Perencanaan dapat dikatakan sebagai fondasi untuk memulai kegiatan. Dalam perencanaan perlu mempertimbangkan beberapa unsur seperti komunikator, pesan, media, khalayak serta efeknya. Langkah pertama dalam pendampingan yaitu dilakukan riset. Riset ini dilakukan oleh program officer, program manager dan direktur eksekutif yang bertujuan ntuk mengetahui masalah serta menggali informasi yang ada di Kabupaten Cirebon dan Yogyakarta.

Selain itu, riset yang dilakukan juga dapat menentukan kriteria daerah yang perlu didampingi hingga pada perencanaan pesan. Pengonsepan masalah dalam perencanaan yaitu pemerintah daerah baik di Kabupaten Cirebon dan Yogyakarta diharapkan lebih responsif seperti memastikan adanya keterbukaan informasi yang salah satunya adalah penganggaran. Untuk Kabupaten Cirebon point permasalahan lebih mengarah kepada gender awareness dan gender responsiveness. Ibu Tatat sebagai program manager menjelaskan:

"Kabupaten Cirebon ini memang seperti Kabupaten biasa yang memang ya perempuan banyak berperan tapi suaranya tidak didengar. Kabupaten Cirebon ini banyak pesantren dan lembaga agama lainnya, cukup kuat ya. Daerah-daerah yang bisa dikatakan agak konservatif, peran perempuannya agak kurang ya"

Sementara untuk Yogyakarta lebih kepada akses ketenagakerjaan seperti yang diungkapkan oleh informan yakni Ibu Megawati:

"Ada fakta bahwa SDM kita rendah, kita butuh peningkatan kualitas jadi mereka butuh untuk latihan kerja. Sejauh mana BLK mampu memberikan ruang itu." 
Berdasarkan dari pengonsepan masalah, maka perencanaan pesan akan lebih terarah. Pesan-pesan kunci atau key messages yang perlu ditekankan dan perlu dirumuskan dari permasalahan isu kemiskinan di daerah Kabupaten Cirebon dan Yogyakarta adalah bagaimana program-program pemerintah daerah tersebut benarbenar menargetkan masyarakat miskin.

Di Yogyakarta, masalah kemiskinan berhubungan dengan akses. Akses yang dimaksud bukan hanya akses mengenai pekerjaan tetapi juga keterampilan. Sejalan dengan hal itu, key message yang perlu ditekankan di Yogyakarta adalah mengintervensi Balai Latihan Kerja (BLK) yang ada di daerah sebagai upaya dalam meningkatkan keterampilan masyarakat terkait. Sedangkan di Kabupaten Cirebon, key message yang perlu ditekankan yaitu pembangunan infrastruktur serta program pelatihan yang mempertimbangkan aspek gender serta pertimbangan pelibatan perempuan dalam forum.

Pada tahap ini, perlu adanya penyusunan perencanaan untuk komunikator yang bertujuan untuk mengetahui peran yang akan diembannya. INFID sebagai komunikator yaitu sebagai penyampai informasi, penyampai usulan kebijakan, penyampai pesan masukan atau tanggapan serta pemberi informasi untuk meningkatkan pengetahuan mitra daerah. Selain itu, INFID sebagai komunikator juga mencoba melakukan pendekatan untuk mendorong keterlibatan semua pihak dalam setiap program untuk pelaksanaan SDGs.

Pertimbangan dalam menentukan media yang tepat dalam perencanaan pendampingan pemerintah daerah yakni bisa dilihat dari penggunaan FGD, lokakarya, sharing knowledge dan audiensi. Penggunaan non mediated communication ini dengan pertimbangan eketifitas karena pesan dari diskusi dapat disampaikan langsung. Hal tersebut dipaparkan oleh Ibu Megawati yaitu:

"Temuan-temuan pun lebih enak didiskusikan secara langsung. Jadi tatap mata dua arah itu, lebih memudahkan kita untuk berkomunikasi karena ketika dua arah ini, kita juga mendapatkan informasi dari pemda ini”.

Penyusunan komunikan dalam perencanaan manajemen komunikasi merupakan langkah yang tidak boleh terlewatkan. Komunikan akan berpengaruh terhadap jalannya pendampingan serta pihak yang memberikan feedback. Komunikan dalam pendampingan pemerintah daerah yaitu salah satunya adalah Bappeda yang merupakan lembaga pemerintah yang merencanakan dan menyusun hal-hal yang berkaitan dengan pembangunan di daerah.

Namun, bukan hanya kepada lembaga pemerintahan saja, INFID juga berkomunikasi dengan Aisyiyah Cirebon dan Koalisi Perempuan Indonesia (KPI) Yogyakara sebagai NGO lokal. Tujuan berkomunikasi dengan NGO lokal dipertimbangkan sebagai pihak yang menjembatani pendampingan kepada lembaga pemerintah masing-masing daerah seperti Bappeda ataupun pemerintah daerah terkait. 
Aisyiyah dipertimbangkan karena memiliki visi pendidikan dan pembinaan perempuan, berikut juga KPI adalah NGO yang mengedepankan isu advokasi kesetaraan gender dan keadilan gender. Melihat dari visi misi tersebut, Aisyiyah dan KPI memiliki tujuan yang sama dengan salah satu fokus SDGs di INFID yaitu tujuan lima (kesetaraan gender).

Pada tahapan perencanaan, riset-riset yang dijalankan ini, dalam teori informasi organisasi merupakan tahapan dari pembuatan untuk menghilangkan kesamaran informasi. Berdasarkan hasil-hasil riset, maka pengonsepan masalah ini menjadi acuan dalam perencanaan pesan. Hal itu dikarenakan agar pesan-pesan yang disampaikan tepat sasaran. Untuk itu, informasi atau pesan yang dikemas disesuaikan dengan permasalahan dari masing-masing daerah. Kabupaten Cirebon fokus pada permasalahan gender awareness dan gender responsiveness sedangkan Yogyakarta fokus pada akses ketenagakerjaan. Dengan adanya pengonsepan permasalahan berdasar riset, peneliti menganalisis bahwa pada tahap ini INFID melakukan pemilihan sebagai bagian dari tahapan untuk mengurangi kesamaran informasi, agar pesan-pesan yang disampaikan jelas dan tidak bias.

Tahapan pemilihan informasi atau pesan juga merupakan tahapan dari pemilihan pada teori informasi organisasi. Pemilihan ini didasarkan untuk menerima beberapa informasi dengan mempersempit bidang agar kesamaran informasi dapat diminimalisir. Dalam mencapai tujuan kemiskinan, selain informasi SDGs secara luas, informasi mengenai pengaruh-pengaruh kesetaraan gender serta pekerjaan yang layak difokuskan. Dalam arti, informasi mengenai pengaruh tersebut dapat diterima karena relevan, yakni berpengaruh dalam pengurangan kemiskinan sebagaimana yang tergambar pada goal tanpa kemiskinan.

\section{Tahap Pengorganisasian Komunikasi INFID dalam Pendampingan Kabupaten Cirebon dan Kota Yogyakarta}

Organizing merupakan tahap penyusunan struktur organisasi yang sesuai dengan tujuan penyiaran sumber daya yang dimiliki dan lingkungan yang melingkupinya. Tujuan dari pengorganisasian ini adalah untuk mengelompokkan kegiatan sumber daya manusia dan sumber daya lainnya yang dimiliki agar pelaksanaan berdasarkan rencana yang sebelumnya dibuat dan disusun dapat dicapai secara efektif.

Program officer merupakan staf yang dikordinasikan sebagai komunikator dalam pendampingan. Penetapan program officer didasari karena memiliki kemampuan managerial, pengetahuan mengenai substansi permasalahan, memiliki gambaran yang dalam mengenai SDGs serta struktur pelaksanaan SDGs di Indonesia. Di tingkatan nasional, direktur eksekutif juga terlibat untuk menetukan aspek strategis dan bertemu dengan high level discussion.

Dalam mengkordinasikan staf internal, pembagian atau spesialisasi kerja berdasarkan SOP yang ada. Di program SDGs, kordinasi dan komunikasi utama melalui program manager, program officer serta program asistensi yang didasarkan 
pada struktur organisasi. Sedangkan pelibatan direktur eksekutif dipertimbangkan dengan beberapa hal. Adanya kerjasama program officer dengan SDGs dan juga ketimpangan karena tujuan tanpa kemiskinan merupakan persinggunngan dari dua program tersebut. Media komunikasi yang dilakukan untuk berkoordinasi dalam menjalankan tugas yaitu melalui email dan pertemuan langsung seperti rapat.

Pengorganisasian pesan-pesan selama proses pendampingan pada pemerintah daerah di Kabupaten Cirebon dan Yogyakarta berputar diantara program manager, program officer dan juga program asisten. Komunikasi vertikal ini dilakukan untuk menyelaraskan agar program pendampingan berjalan efektif. Peneliti menganalisis bahwa adanya double interact dalam teori informasi organisasi. Double interact ini bertujuan untuk memastikan tugas yang dilakukan sudah tepat. Hal ini dapat digambarkan melalui adanya komunikasi dua arah diantara dua level yang berbeda, seperti mengklarifikasi tugas pembuatan format laporan, surat menyurat oleh program asisten berdasarkan arahan dari program officer sebelumnya.

Kemudian, INFID turut berkoordinasi dengan mitra daerah. Di Kabupaten Cirebon INFID berkordinasi dengan Aisyiyah Cirebon. Sedangkan Yogyakarta dengan Koalisi Perempuan Indonesia (KPI) dan Suara Nusa Institut dalam hal ketimpangan. Media yang digunakan untuk mengkordinasikan tugas ataupun kerja yakni publikasi, laporan kegiatan, workplan dengan mitra daerah agar kegiatan pendampingan dapat berjalan sesuai dengan timeline.

\section{Tahap Pengarahan atau Penggerakan Komunikasi INFID dalam Pendampingan Kabupaten Cirebon dan Kota Yogyakarta}

Actuating dalam hal ini bukan hanya pengarahan atau menggerakkan anggota untuk mencapai tujuan tetapi juga sebagai upaya untuk menjadikan perencanaan menjadi terealisasi. Untuk penggiatan komunikasi internal dalam pendampingan pemerintah daerah, pengarahan atau penggiatan di INFID ini dilakukan oleh program manager ataupun direktur eksekutif dengan bertahap atau berjenjang. Media komunikasi yang digunakan yaitu sharing dan rapat bulanan. Adapun pesan yang disampaikan mengenai perkembangan terbaru SDGs yang memang mencakup isu-isu atau tema diluar SDGs sehinga seluruh staf mengetahui informasi terbaru.

Dampak atau efek dari penggiatan komunikasi program berjalan sesuai dengan timeline, informasi dapat menyebar kepada seluruh staf, memudahkan pemahaman di level bawah, memperjelas gambaran kegiatan kepada pelaksana. Hal tersebut sebagaimana yang diterangkan oleh Pak Bona Tua sebagai program officer SDGs, yaitu:

"Dalam artian SDGs ini secara substansi juga mencakup isu-isu atau tema lainnya. Jadi dalam artian, pengampu atau program lainnya juga mendapatkan tambahan atau pengetahuan, bagaimana misalnya strategi atau pengalaman yang dilakukan oleh program SDGs." 
Pendampingan pemerintah daerah dapat pula dikatakan sebagai penggerakan dan pengarahan. Penggerakan dan pengarahan yang dimaksud adalah untuk mengupayakan adanya keberhasilan di SDGs pada masing-masing daerah. Media yang dipilih adalah non mediated communication seperti FGD, lokakarya, workshop, media briefing ataupun press conference untuk memberikan informasi seputar SDGs. Metode komunikasi untuk pengusulan kebijakan kepada pemerintah daerah tidak dilakukan dengan pendekatan yang keras.

Metode komunikasi juga bisa didasarkan kepada mitra atau jaringan dengan memberikan riset, laporan dan capacity building kepada mitra atau jaringan terkait untuk melakukan monitoring terhadap penggunaan anggaran yang kemudian diadvokasikan agar terjadinya perubahan, seperti di Kabupaten Cirebon, diadakannya uji coba tools monitoring SDGs yang turut melibatkan Aisyiyah Cirebon. Kemudian, di Yogyakarta terdapat FGD peer review analisa fiskal dan dialog rencana aksi daerah.

Pesan secara menyeluruh untuk Kabupaten Cirebon dan Yogyakarta yaitu no one leave behind yaitu perempuan yang termasuk biasa ditinggalkan serta pemerintah perlu menempatkan prioritas program. Pesan yang ditekankan mengenai Yogyakarta adalah intervensi BLK dengan adanya keterlibatan banyak pihak seperti Asosiasi Pengusaha Indonesia (APINDO) dan Kamar Dagang dan Industri Indonesia (KADIN).

Tabel I Contoh Kegiatan di Yogyakarta

\begin{tabular}{|c|c|}
\hline Target dan Sasaran Advokasi & Bentuk Kegiatan \\
\hline $\begin{array}{l}\text { Identifikasi gap kebijakan (program, } \\
\text { anggaran dan kelembagaan) di daerah }\end{array}$ & $\begin{array}{ll}\text { - } & \text { Survey need assesment anak muda dan } \\
\text { perempuan terhadap pelatihan kerja } \\
\text { - } \quad \text { Mapping gap kebijakan } \\
\text { ketenagakerjaan } \\
\text { - } \quad \text { Dialog dengan pemerintah di daerah } \\
\text { - } \quad \text { Workshop dengan organisasi } \\
\text { masyarakat sipil } \\
\text { - } \quad \text { Pembuatan website }\end{array}$ \\
\hline $\begin{array}{l}\text { Pemerintah Nasional memiliki Rencana } \\
\text { Aksi Daerah (RAN) SDGs untuk tujuan } 8 \\
\text { yaitu pekerjaan layak dan pertumbuhan } \\
\text { ekonomi }\end{array}$ & $\begin{array}{ll}- & \text { Penyusunan RAN SDGs tujuan } 8 \text { oleh } \\
& \text { konsorsium } \\
\text { - } & \text { FGD dan workshop untuk memperkaya } \\
& \text { RAN SDGs (pelatihan vokasi dan } \\
& \text { pemagangan) } \\
\text { - } & \text { Dialog dengan pemerintah nasional } \\
& \text { terutama kementerian ketenagakerjaan } \\
- & \text { Kunjungan ke BLK } \\
- & \text { Konfrensi pers }\end{array}$ \\
\hline $\begin{array}{l}\text { Pemerintah daerah memiliki draft Perda } \\
\text { tentang pelatihan kerja }\end{array}$ & $\begin{array}{ll}\text { - } & \text { Penyusunan kertas kebijakan oleh } \\
\text { masyarakat sipil } \\
\text { - } \\
\text { Dialog kebijakan dengan pemerintah } \\
\text { daerah } \\
\text { - } & \text { Asistensi pemerintah dalam }\end{array}$ \\
\hline
\end{tabular}


Manajemen Komunikasi Infid dalam Pendampingan PEMDA Kabupaten Cirebon dan Kota Yogyakarta Mencapai Sustainable Development Goals

\begin{tabular}{|c|c|}
\hline Target dan Sasaran Advokasi & Bentuk Kegiatan \\
\hline & $\begin{array}{l}\text { penyusunan naskah akademik Perda } \\
\text { bersama universitas dan sektor swasta }\end{array}$ \\
\hline $\begin{array}{l}\text { Pemerintah daerah memiliki perda } \\
\text { pelatihan kerja }\end{array}$ & $\begin{array}{ll}\text { - } & \text { Dialog kebijakan dengan pemerintah } \\
\text { daerah dan nasional } \\
\text { - } \\
\text { Penguatan konsorsium masyarakat } \\
\text { sipil }\end{array}$ \\
\hline $\begin{array}{l}\text { Terbangunnya kemitraan antara } \\
\text { pemerintah daerah, akademisi, masyarakat } \\
\text { sipil dan sektor swasta di dalam pelatihan } \\
\text { kerja }\end{array}$ & $\begin{array}{ll}\text { - } & \text { Dialog regular multi pihak mengenai } \\
\text { pelatihan kerja } \\
\text { - } & \text { Media briefing, jurnalis fellowship } \\
\text { - } & \text { Konfrensi pers dan lain-lain }\end{array}$ \\
\hline
\end{tabular}

Pelaksanaan pendampingan di Yogyakarta dapat dilihat dengan pendekatan advokasi melalui engagement dan dialog dengan pemerintah daerah, DPRD, akademisi, media dan pihak swasta. Salah satu dialog yaitu dengan pemerintah khususnya kementerian ketenagakerjaan dengan masyarakat sipil mengenai rencana aksi SDGs.

Dialog dengan pemerintah daerah lebih kepada dialog kebijakan sedangkan terdapat dialog regular antar pihak di daerah mengenai pelatihan kerja. Pelaksanaan pendampingan lainnya berbentuk workshop dengan organisasi masyarakat sipil, FGD dan workshop untuk memperkaya rencana aksi SDGs (pelatihan vokasi dan pemagangan), serta dilakukannya konferensi pers, media briefing serta jurnalis fellowship untuk menguatkan dukungan publik terhadap pelatihan kerja.

Kemudian, pesan yang ditekankan mengenai Kabupaten Cirebon sesuai dengan semangat SDGs yang responsif gender, inklusif dan transformatif seperti penyusunan pelatihan kerja yang mempertimbangkan aspek gender serta peningkatan capacity building agar perempuan dapat dilibatkan dalam pengambilan keputusan.

Tabel II Contoh Kegiatan di Kabupaten Cirebon

\section{Outcome}

Terbentuknya kepanitiaan bersama sekaligus komite penyusunan Rencana Aksi SDGs di Kabupaten Cirebon yang terdiri atas organisasi perempuan, masyarakat sipil dan pemerintah dalam pelaksanaan SDGs

\section{Kegiatan}

Pertemuan dengan organisasi masyarakat sipil mitra MAMPU, Kibbla, GOW dan perguruan tinggi di Kabupaen Cirebon Diskusi terbatas dengan Bappeda dan organisasi perangkat daerah di Kabupaten Cirebon

Audiensi dengan Bupati Kabupaten Cirebon

Lokakarya tenatng inisiasi pembentukan panitia bersama yang dihadiri oleh organisasi masyarakat sipil, organisasi perangkat daerah dan perguruan tinggi

Media briefing untuk media lokal 
Keterlibatan perempuan ini juga dapat terlihat dalam suatu pendampingan yakni untuk mendorong terbentuknya kepanitiaan bersama sekaligus komite penyusunan Rencana Aksi SDGs di Kabupaten Cirebon yang terdiri dari organisasi perempuan, masyarakat sipil dan pemerintah dalam pelaksanaan SDGs. Pelaksanaan pendampingan yang dilakukan diantaranya pertemuan langsung, diskusi terbatas, audiensi, lokakarya dan juga media briefing. Dampak dari pelaksanaan pendampingan tersebut bukan hanya mendorong dukungan dan komitmen dari pemerintah daerah seperti Bappeda, tetapi juga mendorong keterlibatan dan dukungan media, organisasi masyarakat sipil serta woman right organization (WRO) yang diimplementasikan salah satunya melalui pertemuan dengan organisasi mitra MAMPU, Kibbla, GOW dan perguruan tinggi di Kabupaten Cirebon.

Pada tahap pengarahan atau penggerakan, media penyampai pesan dalam pendampingan pemerintah daerah berupa FGD, lokakarya, workshop ataupun seminar. Penggunaan media non mediated communication ini, merupakan siklus perilaku (behavior cycles) dalam teori informasi organisasi. Dimana dalam menyampaikan usulan, masukan ataupun advokasi kebijakan memang merupakan media yang selalu INFID lakukan, termasuk dalam pendampingan pemerintah daerah Kabupaten Cirebon dan Yogyakarta. Kemudian, pelibatan pemerintah dan organisasi pemerintah dalam setiap pendampingan, baik dalam bentuk diskusi, FGD, seminar dan bentuk lainnya, merupakan bentuk aturan tindakan atau assembly rules yang menuntun pilihan kebiasaan yang digunakan untuk menyelesaikan proses-proses pendampingan. Keterlibatan dari berbagai pihak ini merupakan assembly rules, dimana sesuai dengan cara kerja SDGs yaitu mendorong dan melibatkan multipihak.

Penerapan manajemen komunikasi INFID bertujuan untuk menimbulkan dampak komunikasi seperti dampak kognitif, afektif serta konatif kepada mitra dan pemerintah daerah terkait. Penggunaan media dalam pendampingan lebih menggunakan non mediated communication terutama pada tahap pengorganisasian dan pengerahan komunikasi. Hal itu dipertimbangkan karena adanya umpan balik langsung atau immediated feedback. Penggunaan berbagai media juga dapat terlihat dengan adanya pelibatan pers terutama pada tahap pengerahan komunikasi. Hal itu dapat terlihat adanya konfrensi pers, media briefing serta jurnalis fellowship di Yogyakarta dan media briefing untuk media lokal di Kabupaten Cirebon. Keterlibatan dengan pers menekankan adanya publicly yakni dikarenakan pesannya tidak ditujukan kepada perseorangan tertentu yang ekslusif, tetapi bersifat terbuka untuk umum atau publik.

\section{Tahap Pengendalian Komunikasi INFID dalam Pendampingan Kabupaten Cirebon dan Kota Yogyakarta}

Tahap pengendalian atau controlling bertujuan untuk melihat, memantau jalannya organisasi dan kegiatan yang dilakukan, menilai tercapainya tujuan serta 
melihat faktor apa saja yang dapat mendukung sekaligus menghambat baik untuk organisasi ataupun untuk kegiatan terkait. Di INFID, terdapat kegiatan controlling dalam pendampingan daerah yang disebut monitoring dan evaluasi (monev). Pengendalian kepada pemerintah daerah dilakukan oleh program officer dan juga berkolaborasi dengan program manager dan program asisten. Controlling diutamakan dapat dilakukan oleh mitra daerah. Di Kabupaten Cirebon berkordinasi dengan Aisyiyah Cirebon dan di Yogyakarta berkordinasi dengan Koalisi Perempuan Indonesia serta Suara Nusa Institut dalam hal ketimpangan.

Pendekatan komunikasi dapat dilakukan secara langsung melalui email, whatsapp juga telepon ataupun mengundang ke dalam lokakarya. Tetapi dengan mitra daerah lainnya, mereka sendiri yang melakukan kordinasi langsung dengan Aisyiyah Cirebon ataupun KPI Yogya. Mengenai hal tersebut, program officer SDGs menjelaskan:

"Supaya, kembali lagi, mitra daerah itu pertama secara kapasitas naik, kemampuan advokasi, pengetahuan dan lainnya. Terus yang kedua juga, secara kapasitas kemampuan kita juga tidak bisa untuk ngurusin semua daerah langsung."

Riset dapat dijadikan media untuk mengetahui sejauh mana program pemerintah dijalankan. Di Cirebon, berkordinasi dengan di Cirebon terdapat koordinasi dengan Universitas Muhammadiyah Cirebon (UMC), Bappeda, DPPKBP3A, KPI Cirebon, WCC Balqis dan Dinas sosial Cirebon. Sedangkan di Yogyakarta terdapat kordinasi dengan CIQAL, Bappeda DIY, Kadin DIY, PBHI DIY, Forum LSM DIY, Aisyiyah Pusat atau DIY. Hasil-hasil riset di diseminasikan melalui FGD, lokakarya, dan konfrensi pers. Faktor keberhasilan dari adanya pendampingan pemerintah daerah dapat dilihat dari dua hal, yakni pertama, pemerintah mengikutsertakan organisasi non pemerintah. Kedua, ada faktor keterlibatan masyarakat melahirkan trust kepada pemerintah sebagaimana yang diterangkan oleh Pak Bona Tua sebagai key informan II:

"Jadi dalam artian, dari sisi paling mudah kita melihat, memonitor dari sisi angka, kuantitatif, data dan statistik dan kita juga melihat dari sisi proses, terlepas dari pencapaiannya gagal atau tidak. Pelibatan multipihak, itu sudah hal-hal praktik baik, entah apakah itu gagal atau tidak, kan ada faktorfaktor lain yang bisa mempengaruhi kemiskinan."

Dalam tahapan pengendalian, implementasinya bukan kepada pengendalian ataupun controlling kepada komunikator, tetapi lebih kepada komunikan yaitu pemerintah daerah dari Kabupaten Cirebon dan juga Yogyakarta. Komunikator yaitu pihak INFID yang berkordinasi dengan organisasi non pemerintah lainnya lebih melihat proses dan pengawalan dari kebijakan-kebijakan yang dilakukan oleh 
pemerintah. Adapun pengendalian dalam tahap ini juga bukan melakukan pengendalian atau controlling dalam penggunaan medianya, tetapi media komunikasi ini menjadi saluran untuk mengetahui sejauh mana kebijakan. Sehingga yang lebih ditekankan pada tahap ini adalah pengendalian kepada komunikan yakni pemerintah daerah.

\section{Kesimpulan}

Berdasarkan hasil penelaahan data di lapangan dan pembahasan, dapat disimpulkan bahwa manajemen komunikasi INFID dalam melakukan pendampingan pemerintah daerah di Kabupaten Cirebon dan Yogyakarta cukup berbeda. Hal ini didasarkan pada pesan, komunikan serta pola komunikasi yang digiatkan dalam pelaksanaannya. Pesan dalam pengurangan kemiskinan pada Kabupaten Cirebon lebih mengarah kepada aspek gender dimana permasalahan gender responsiveness dan gender awareness perlu digarisbawahi. Sedangkan di Yogyakarta, pesan lebih mengarah kepada sisi ketenagakerjaan.

Banyaknya aktivitas komunikasi yang dilakukan dalam pendampingan pemerintah daerah, membuat aktivitas komunikasi INFID menjadi dinamis. Jika dilihat dari segi komunikan, INFID selalu berkomunikasi pada mitra-mitra terkait seperti Aisyiah Cirebon di Kabupaten Cirebon. Sementara di Yogyakarta terdapat KPI Yogya, Suara Nusa Institut dalam hal ketimpangan serta pihak swasta seperti KADIN dan APINDO. Selain mitra daerah, INFID juga mendorong keterlibatan pihak lain seperti Bappeda, dinas sosial, kementerian ketenagakerjaan ataupun pemerintah daerah di Kabupaten Cirebon dan Yogyakarta untuk mengentaskan masalah-masalah yang mempengaruhi faktor-faktor kemiskinan.

Manajemen komunikasi INFID dalam pendampingan di Kabupaten Cirebon dan Kota Yogyakarta cukup sistemik dan terintegrasi terutama dalam tahap perencanaan, pengorganisasian serta penggerakan atau pengarahan. Pada tiga tahap tersebut, unsurunsur komunikasi yaitu komunikator, pesan, media, komunikan atau khalayak diidentifikasi dan turut digiatkan dalam penerapan. Pada tahap pengorganisasian dan pengarahan, manajemen komunikasi INFID menjadi dua bentuk yaitu internal dan eksternal. Internal dilakukan kepada staf yang bekerja di INFID sedangkan eksternal dilakukan kepada mitra daerah dan pemerintah daerah. Dalam tahapan pengendalian yang dilakukan oleh INFID dalam pendampingan kepada pemerintah daerah. Terdapat unsur dari manajemen komunikasi yang tertinggal seperti komunikator, media serta efeknya. Pengendalian ini hanya berfokus pada komunikan saja atau khalayak saja sehingga kurang adanya sinergitas dan efektifitas dalam hal pengendalian. 
Manajemen Komunikasi Infid dalam Pendampingan PEMDA Kabupaten Cirebon dan Kota Yogyakarta Mencapai Sustainable Development Goals

\section{BIBLIOGRAFI}

Abidin, Yusuf Zainal. (2015). Manajemen Komunikasi: Filosofi, Konsep, dan Aplikasi. Bandung: Pustaka Setia.

Avianto, Bhakti Nur. (2017). Analisis Pengembangan Home Industri Unggulan Kaos Etnik Khas Cirebon Di Kecamatan Plered Kabupaten Cirebon. Syntax Literate; Jurnal Ilmiah Indonesia, 2(5), 48-57.

Azwar, Budi. (2014). Program Pemberdayaan Masyarakat Dalam Penanggulangan Kemiskinan di Kabupaten Kampar (Studi Tentang Efektifitas Bantuan Dana Bergulir Sektor Agribisnis). MENARA, 13(1), 102-117.

Fatimah, Siti, Arifin, Isep Zaenal, \& Sumpena, Deden. (2019). Komunikasi Pemberdayaan Masyarakat melalui Kegiatan Program Keluarga Harapan. Prophetica: Scientific and Research Journal of Islamic Communication and Broadcasting, 5(1), 63-80.

Hoelman, Mickael B., Parhusip, Bona Tua Parlinggoman, Eko, Sutoro, Bahagijo, Sugeng, \& Santono, Hamong. (2016). Sustainable Development Goals-SDGs Panduan Untuk Pemerintah Daerah (Kota dan Kabupaten) dan Pemangku Kepentingan Daerah. Sustain Dev, 1-92.

Kartika, Ray Septianis. (2012). Partisipasi masyarakat dalam mengelola Alokasi Dana Desa (ADD) di Desa Tegeswetan dan Desa Jangkrikan Kecamatan Kepil Kabupaten Wonosobo. Jurnal Bina Praja: Journal of Home Affairs Governance, 4(3), 179-188.

Moleong, Lexy J. (2019). Metodologi penelitian kualitatif. Bandung: PT Remaja Rosdakarya.

Saragih, Ramainim, \& Agung, Sarwititi. (2018). Peran Komunikasi Politik Pemerintah Dalam Upaya Peningkatan Partisipatif Masyarakat Dalam Pemanfaatan Dana Desa (Penggalian Bentuk Komunikasi Warga Masyarakat Terhadap Penggunaan Dana Desa). Reformasi: Jurnal Ilmiah Ilmu Sosial Dan Ilmu Politik, 7(1).

Sarmiati, Sarmiati. (2014). Strategi Komunikasi Berbasis Kearifan Lokal dalam Penanggulangan Kemiskinan. Jurnal Ilmu Komunikasi, 10(1).

Sugiyono. (2014). Metode Penelitian Manajemen. Bandung: Alfabeta.

Suhaeri, Suhaeri. (2018). Strategi Komunikasi Inovasi Dalam Meminimalisir Konflik Horizontal Pengemudi Taksi Online Dan Konvensional Di Kota Bandung. Syntax Literate; Jurnal Ilmiah Indonesia, 3(2), 122-131.

Suprapto, Tommy. (2011). Pengantar Ilmu Komunikasi dan Peran Manajemen dalam Komunikasi. CAPS. 
Salsabila Pratiwi dan Yayu Sriwartini

Syamsi, Syahrul. (2015). Partisipasi masyarakat dalam mengontrol penggunaan anggaran dana desa. JISIP: Jurnal Ilmu Sosial Dan Ilmu Politik, 3(1).

Triyanto, Deni. (2018). Analisis Kinerja Pendamping Desa Dalam Upaya Membangun Kemandirian Desa. Mimbar: Jurnal Penelitian Sosial Dan Politik, 7(2), 56-62. 